
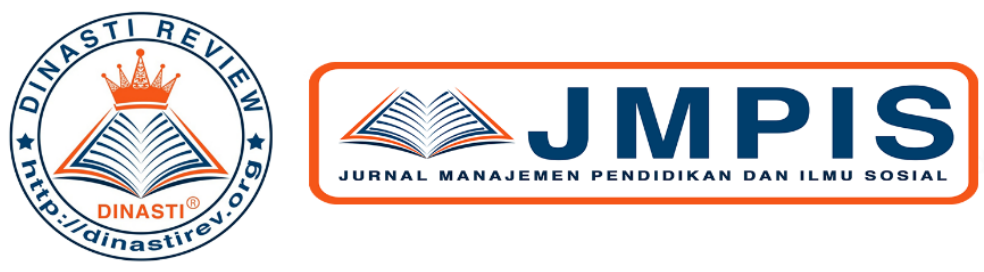

+6281387654578 (3)

+6281387654578 (Q)

https://dinastirev.org/JMPIS (-)

dinasti-info@gmail.com (․)

\title{
PENTINGNYA KEPUASAN PELANGGAN PADA SUATU BISNIS
}

\section{Wafi Wicaksana}

Universitas Mercu Buana,DKI Jakarta, Indonesia

\begin{tabular}{|c|c|}
\hline $\begin{array}{l}\text { ARTICLE INFORMATION } \\
\text { Received: } 24 \text { Mei } 2020 \\
\text { Revised: } 30 \text { Mei } 2020 \\
\text { Issued: } 1 \text { Juni } 2020 \\
\text { Corresponding author: first } \\
\text { author } \\
\text { E-mail: } \\
\text { wafiwicaksana68@gmail.com } \\
\text { DOI:10.38035/JMPIS }\end{array}$ & $\begin{array}{l}\text { Abstrak: Pada era digital saat ini banyak sekali } \\
\text { persaingan pada dunia bisnis,kepuasan konsumen } \\
\text { merupakan salah satu modal utama dalam } \\
\text { memulai suatu bisnis. dalam satu istilah terdapat } \\
\text { sebutan bahwa pelanggan adalah raja. karena } \\
\text { dengan adanya konsumen,suatu bisnis dapat } \\
\text { berkembang dan bertahan. kepuasan konsumen } \\
\text { adalah suatu indikator yang menunjukkan respon } \\
\text { kualitas suatu produk yang dibuat dan suatu } \\
\text { pelayanan yang sudah diberikan.Apabila respon } \\
\text { yang mereka berikan bagus, maka mereka akan } \\
\text { loyal terhadap pruduk yang kita buat. maksud } \\
\text { dari konsumen yang loyalitas ialah bahwa } \\
\text { konsumen tersebut akan membeli produk kita } \\
\text { secara berulang dan tidak memilih merek merek } \\
\text { yang menjadi pesaing dalam bisnis kita. Maka } \\
\text { dengan adanya hubungan yang positif dengan } \\
\text { Kepuasan konsumen kita maka hal tersebut akan } \\
\text { meningkatkan profit bagi usaha kita setiap } \\
\text { bulannya. } \\
\text { Kata Kunci: Kepuasan konsumen, Loyalitas } \\
\text { Pelanggan, Bisnis }\end{array}$ \\
\hline
\end{tabular}

\section{PENDAHULUAN}

Pada era digital saat ini banyak sekali persaingan pada dunia bisnis,kepuasan pelanggan adalah salah satu kunci utama. Mengapa kepuasan konsumen dapat disebut sebagai hal yang penting dalam berbisnis? Karena apabila tingkat kepuasan konsumen kita tinggi,maka konsumen tersebut bepotensi memiliki loyalitas untuk membeli Kembali barang tersebut. Kemudian karena hal tersebut bisnis yang kita buat maka dapat bertahan lama dan terus meningkatkan omzet yang kita peroleh pada setiap bulannya. Selain dengan keuntungan tersebut apabila bisnis kita sudah terkenal dengan pelayanan terhadap konsumen ,maka hal tersebut juga akan membuat konsumen kita semakin banyak dari hari ke hari.kepuasan konsumen dapat menunjukan bahwa bisnis yang dijalankan tersebut akan berjalan dengan baik atau tidak. Jika tingkat kepuasannya tinggi maka bisnis yang dijalankan akan semakin baik sedangkan apabila tingkat kepuasan konsumen rendah maka bisnis yang kita jalankan akan tidak berjalan dengan baik bahkan lama-kelamaan akan mengalami bangkrut. 
Pernyataan tersebut sudah saya buktikan sendiri,saya sejak SMA kelas 2 sudah memulai bisnis usaha online dengan cara menjadi reseller Di marketplace yang ada di Indonesia( Tokopedia, Bukalapak, Sophie, dan blibli). Awal memulai bisnis saya saya masih tidak mengerti tentang pentingnya kepuasan suatu konsumen, Saya hanya memikirkan Bagaimana cara saya untuk mendapatkan keuntungan yang banyak pada setiap bulannya. Seiring berjalannya waktu Pada suatu hari saya pernah mendapatkan suatu ulasan yang yang tidak bagus. karena barang yang saya kirim ternyata mengalami kerusakan pada saat pengiriman karena saya pada saat itu hanya mempacking produk saya dengan menggunakan kantong plastik. setelah adanya hal tersebut saya pun mulai mencoba mencari Bagaimana cara mempacking produk yang baik agar tidak mengalami kerusakan pada saat pengiriman, Akhirnya saya pun menggunakan packing Bubble wrap dan menempelkan stiker fragile pada produk yang saya kirim. Setelah saya menggunakan packing Bubble wrap dan stiker fragile otomatis biaya operasional yang saya keluarkan semakin besar teatapi hal tersebut berbanding lurus dengan keuntungan yang saya terima setiap bulannya. ternyata dengan menggunakan packing-an tersebut tingkat kepuasan konsumen toko saya pun semakin tinggi dan membuat konsumen dan omset yang saya terima setiap bulannya pun semakin besar. Mungkin contoh lainnya kalian bisa melihat brand-brand besar yang masih terbilang baru dalam memulai bisnisnya tetapi orang sudah banyak yang membeli produk atau menggunakan jasa yang mereka jual. Contohnya seperti Xiaomi, antar aja, sicepat dan lain sebagainya. setelah saya teliti dari berbagai sumber ternyata mereka bisa berkembang dengan pesat karena produk atau jasa yang mereka tawarkan sangat baik sehingga konsumen mereka banyak yang merasa puas dengan pelayanan tersebut.

\section{KAJIAN PUSTAKA \\ Bisnis}

Bisnis menurut Huat,TChwee (1990) merupakan semua aktifitas yang dilakukan oleh institusi untuk memproduksi suatu barang dan jasa untuk kehidupan seharihari.aktifitas tersebut dilakukan untuk memenuhi kebutuhan manusia

Steinford 1979 menyatkan bahwa "Business is an institution which produces goods and services demanded by people." Artinya bahwa bisnis adalah kegiatan suatu institusi/lembaga yang memproduksi barang dan jasa karena adanya permintaan dari masyarakat .Bila permintaan atas kebutuhan masyrakat tersebut banyak,maka produksinya akan ditingkatkan dan memperoleh keuntungan.

Griffin ebert 1996 menyatakan bahwa "Business is all those activities involved in providing the goods and services needed or desired by people". Yang artinya bisnis merupakan aktifitas yang menyediakan barang dan jasa yang diperlukan atau diinginkan oleh masyrakat.dalam menyediakan barang atau jasa tersebut dapat dilakukan oleh semua orang,baik dalam bentuk perusahaan yang berbadan hukum,seperti ojek online dan supermarket ataupun tidak berbadan hukum,seperti pedagang kaki lima.

\section{Pelanggan}

Pelanggan menurut Griffin (2007:31) merupakan seseorang yang menjadi terbiasa untuk membeli barang atau produk yang kita jual. Hal tersebut terjadi karena adanya pembelian dan hubungan dengan pelanggan yang baik dalam kurun waktu tertentu.orang yang dapat disebut pelanggan yaitu apabila memili interaksi yang kuat dan melakukan pembelian secara berulang.apabila jika baru pertamakali beli atau tidak berulang maka disebut sebagai pembeli.

Pelanggan berdasar pada UU Pelanggan adalah kegiatan orang yang memakai barang atau jasa yang diperjualbelikan masyarakat dan bukan untuk diperjual belikan. 


\section{Kepuasan Konsumen}

Kotler dan Keller (2009 : 138) berpendapat bahwa kepuasan konsumen adalah seseorang yang merasa puas ataupun kecewa yang timbul terhadap ekspetasi atas produk atau jasa yang mereka gunakan.

Kotler dan Amstrong (2008 : 16) berpendapat bahwa kepuasan konsumen merupakan persepsi konsumen terhadap kinerja suatu produk yang dibeli berdasarkan ekspetasi yang diharapkan.Apabila produk tidak sesuai dengan ekspektasi maka pelanggan akan kecewa dan tingkat kepuasannya menurun,tetapi jika produk sesuai dengan yang diharapkan maka pelangaan akan merasa senang dan tingkat kepuasannya akan meningkat

Kepuasan Konsumen menurut Lupiyoadi dan Hamdani (2006 : 192) adalah perilaku dimana seseorang membadingkan atas kinerja suatu produk ( jasa ) yang diterima dengan yang mereka harapkan.

\section{Loyalitas}

Fandy Tjiptono (2000:110) berpendapat bahwa loyalitas adalah komitmen pelanggan terhadap suatu produk berdasarkan sikap yang baik dan nampak dalam pembelian berulang secara konsisten.

Hermawan Kartajaya (2004:78) berpendapat bahwa loyalitas adalah bentuk dari kebutuhan manusia untuk memiliki, mendukung, merasa aman, membangun keterikatan, dan menciptakan keterikatan emosional terhadap produk.

Gramer dan Brown (Utomo 2006:27) berpendapat bahwa loyalitas adalah konsumen melakukan pembelian dan menggunakan produk atau jasa secara berulang dalam jangka waktu yang Panjang.

\section{METODE PENELITIAN}

Metode Penulisan artikel ini adalah dengan metode deskriftif kualitatif dan Library Research. Dimana Metode deskkriptif kualitatif adalah penelitian yang meneliti dan menjelaskan obyek penelitian berdasarkan fakta-fakta yang ada.Nawawi dan Martini (1996: 73). Dan Metode Library Research adalah penelitian yang lebih memerlukan olahan filosofis dan teoritis daripada uji empiris dilapangan Noeng Muhadjir (1996:169). Selain itu saya juga menggunakan sumber yang berasal dari pengalaman saya pribadi sebagai salah satu penjual di markpetlace Indonesia (Tokopedia,Bukalapak,Shopee,dan Blibli).

\section{HASIL DAN PEMBAHASAN}

\section{Ada beberapa jenis pelanggan,seperti :}

1.Pelanggan Internal

Adalah jenis pelanggan yang biasanya akan menjual kembali barang atau jasa yang dibeli kepada orang lain sehingga mereka tidak menggunakanbarang atau jasa tersebut.Biasanya juga perusahaan akan memberikan suatu harga khusus untuk pelanggan tipe ini.Contohnya adalah para reseller dan dropshipper.

\section{Pelanggan Eksternal}

Adalah jenis pelanggan yang menggunakan produk ataupun jasa yang.Biasanya orang akan membeli karena produk atau jasa yang kita jual sudah mendapatkan kepercayaan atas mutu dan kualitasnya.Contohnya adalah para pembeli. 
3.Pelanggan Antara

Adalah pelanggan yang hanya sebagai perantara antara perusahaan dengan pembeli.Contohnya adalah agen-agen yang menawarkan hotel,tiket perjalan dan lain sebagainya

Berdasarkan pengalaman saya,ada beberapa tipe pelanggan,seperti :

1.Tipe Cerewet

Tipe seperti ini biasanya ia akan sangat bertanya mengenai produk yang akan mereka beli.

\section{Tipe Ngeseli}

Tipe ini hamper mirip dengan tipe cerewet,tetapi basah yang mereka gunakan benarbenar sangat arogan dan sombong.Untuk tipe ini dalam menghadapinya harus benarbenar sabar dalam menghadapinya.karena jika tidak,kita malah akan ikut terpancing emosi

\section{Tipe Pendiam}

Tipe ini biasanya gk banyak bertanya,bahkan tidak bertanya.karena mereka sudah mengerti produk yang akan mereka beli.

4.Tipe ramah dan baik hati

Untuk tipe ini,merupakan pelanggan yang sangat enak untuk di tanggapi.Karena mereka dalam bertanya sangat ramah dan kadang ada juga candaanya saat mereka bercanda.

Meskipun setiap tipe pelanggan memiliki perbadaan dalam menghadapinya.tetapi kita harus tetap melayani mereka dengan baik.karena mereka merupakan calon pelanggan loyal dimasa depan

Kemudian ada Faktor yang mempengaruhi perilaku pelanggan dalam memilih produk atau jasa yang akan mereka gunakan

1.Yang pertama karenan adanya faktor dari kebiasaan,perbedaan social dan hal lainya. Hal tersebut menjadi dasar pelanggan dalam berperilaku(dapat mempercepat dan juga dapat memperlambat)

2. Yang kedua karaena adanya faktor dari sifat,kepribadia,life style dan wawasan.sesorang dapat terpengaruh dalam pengambilan keputusan jika ia melihat orang lain juga menggunakannya

Selain itu,berdasarkan pada pengalaman saya pribadi,pelanggan dalam suatu bisnis is the key(kunci).Karena dengan adanya pelanggan,maka bisnis yang akan atau sedang kita jalankan dapat terus berjalan. Maka dari itu,kita sebagai pebisnis harus sangat dapat mempertahankan pelanggan yang kita punya,jangan sampai pelanggan kita pergi ke pesaing kita.Bahkan saking pentingnya pada tanggal 20 April 1999 dibuat UndangUndang Perlindungan Konsumen(UUPK) yang artinya hak-hak konsumen Indonesia mendapat perlindungan hukum. 


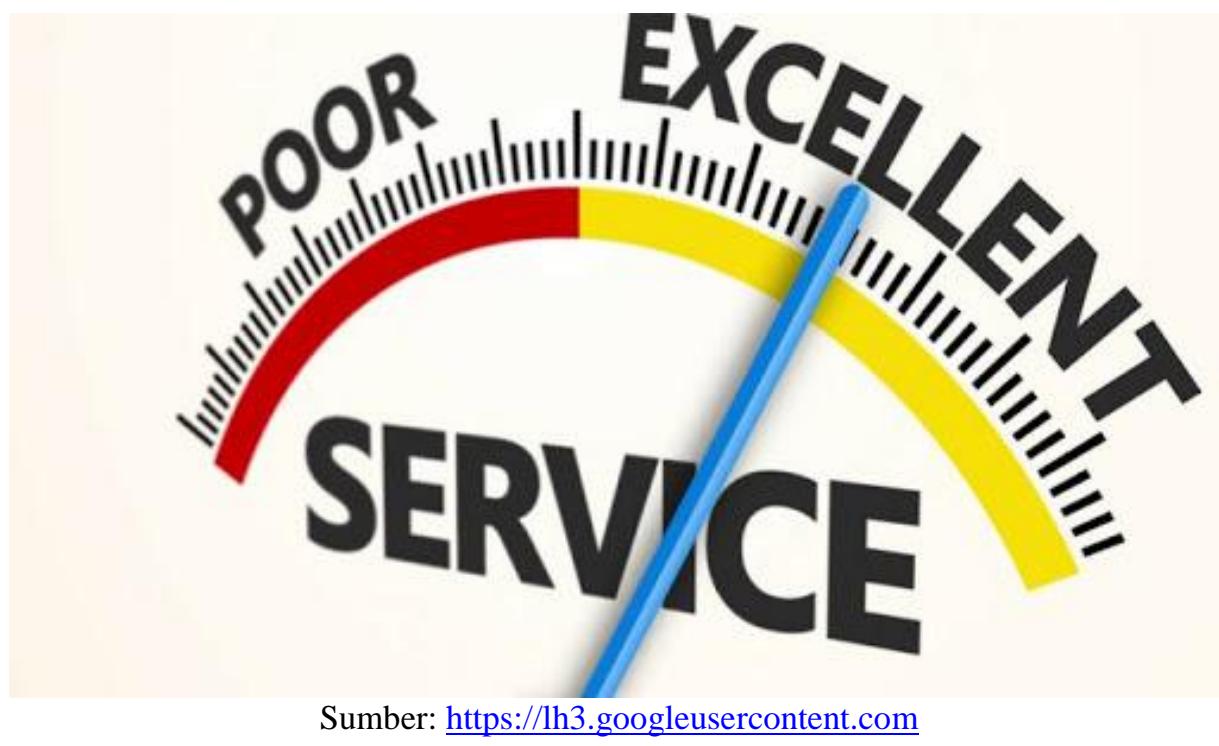

maka dari itu untuk mempertahankan pelanggan kita adalah dapat dilakukan dengan cara menjaga dan meningkatkan kepuasan pelanggan kita.untuk melakukan hal tersebut,kita dapat melakukannya dengan cara memberikan pelayan yang optimal/terbaik bagi setiap pelanggan.Misalkan,apabila adan pelanggan yang bertanya,maka kita harus memberikan jawaban secara jelas dan detail meskipun pelanggan tersebut belum tentu membeli produk tersebut.Kemudian apabila terdapat keluhan atau complain terhadap produk yang kita jual.maka kita harus menjelaskannya secara jujur jika benar kerusakannya terjadi karena terjadi eror atau kerusakan pada produk(bukan rusak karena pelanggan),jangan sampai berbohong dengan alasan yang berbelit-belit. Kemudian dapat memberikan pakaging yang menarik dan safety terhadap produk yang kita kirim kepada pelanggan,untuk menghidari terjadinya kerusakan selama proses pengiriman.

Dan yang menurut saya paling penting adalah memberikan benefit atau promo khusus kepada pelanggan kita.seperti gratis ongkir,potongan harga/diskon, ataupun berupa Undian berhadiah. Contoh perusahaan yang berhasil mendapatkan tingkat kepuasan pelanggan tinggi adalah Ace Hardware Indonesia

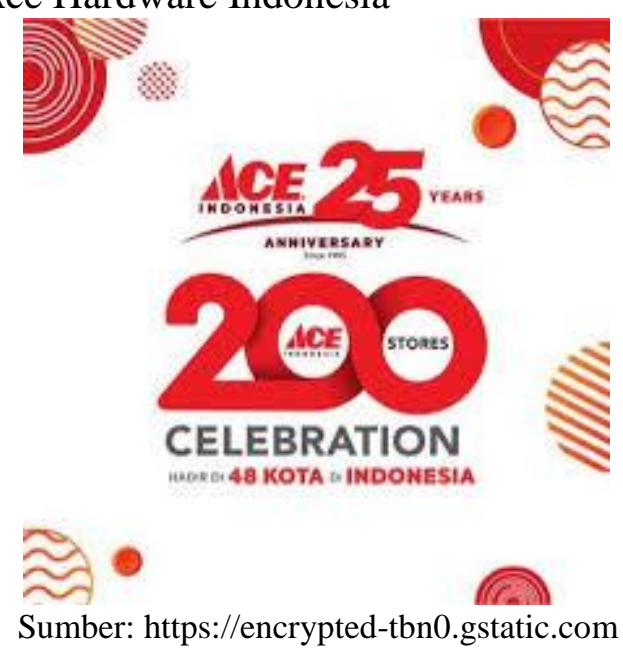

Sejarah singkatnya Ace hardware Indonesia pertama kali didirikan pada tahun 1995 sebagai anak dari PT kawan lama sejahtera.Toko yang mereka buka pertamakali yaitu di Karawaci,Banten pada tahun 1996.Hingga tahun 2018 mereka mempunyai hingga 188 toko yang tersebar pada 44 kota di Indonesia dan sudah memiliki lebih dari 2,5 juta member.Jumlah itu pun pasti akan terus bertambah setiap tahunnya. 
Visi Misi yang diterapkan oleh Ace Hardware Indonesia adalah

Visi

"Kami berusaha menjadi pusat ritel perlengkapan rumah dan gaya hidup yang terdepan di Indonesia."

Misi

"Kami bertujuan memberikan pilihan lengkap untuk produk berkualitas tinggi dengan harga kompetitif, ditunjang pelayanan pelanggan oleh tim profesional."

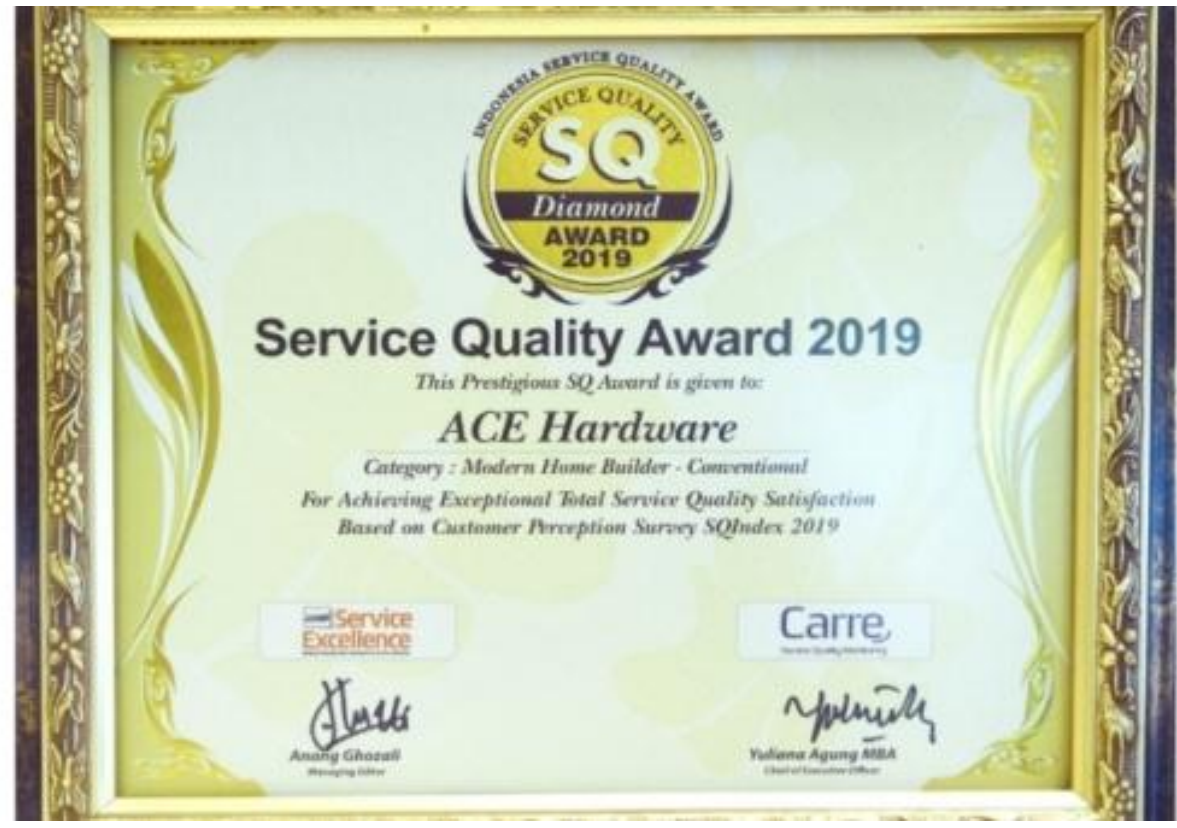

Sumber: https://corporate.acehardware.co.id

Itu adalah salah satu bukti penghargaan yang diberikan kepada Ace hardware Indonesia pada ajang service quality award 2019 untuk kategori modern home builder.Penghargaan tersebut diberikan kepada perusahaan yang berhasil mendapatkan tingkat kepuasan pelanggan tertinggi berdasarkan customer perception survey SQindex 2019.

Memang Untuk Ace hardware saya akui pelayanan yang mereka berikan sangat bagus terhadap para pelanggannya.Pelayanan yang memberikan nilai lebih terhadap Ace Hardware adalah seperti,jika barang yang diinginkan tidak ada di gerai ace tersebut,maka pihak Ace pada gerai tersebut dapay menginfokan di gerai mana yang terdapat barang yang kita inginkan,dan lebih bagusnya barang yang kita inginkan tersebut dalam minta dikirimkan langsung kerumah kita(terdapat syarat dan ketentuannya) atau mengambilnya sendiri di gerai ace tersebut.

\section{KESIMPULAN DAN SARAN}

\section{Kesimpulan}

Berdasarkan hal diatas saya dapat menyimpulkan :

1. Pelanggan adalah suatu kompenen yang sangat penting dalam suatu bisnis karena tanpa adanya pelanggan,suatu bisnis tidak dapat berjalan.

2. Salah satu cara untuk mempertahankan pelanggan yaiut dengan cara meningkatkan kepuasa pelanggan. 
3. Kita bisa mengambil contoh dari Aca hardware Indonesia,mereka sangat menjaga kepuasan pelanggan mereka.Sehingga perusahaan tersebut dapat memiliki banyak gerai yang tersebar di seluruh Indonesia.

\section{Saran}

Saya menyarankan kalian yang ingin memulai menjalankan suatu bisnis,kalian harus bisa mendapatkan pelanggan dan juga harus menjaga nilai kepuasannya,sehingga usaha yang akan kalian jalankan dapat berjalan dengan baik.

\section{DAFTAR RUJUKAN}

Jibu,Taufiq,2013.Artikel kepuasan dan loyalitas konsumen.tafiqjibu.com. https://www.taufiqjibu.com/2013/03/31/artikel-kepuasan-dan-loyalitaskonsumen/.(31 maret 2013)

Hani,2016.kepuasan konsumen(customers satisfaction).blogspot.com. http:// hani 30 9.blogspot.com/2016/12/kepuasan-konsumen-customers-satisfaction.html.(14 desem ber 2016)

Hindayat,Anwar,2012.Penjelasan Lengkap Tentang Penelitian Kualitatif,statistikian. https://www.statistikian.com/2012/10/penelitian-kualitatif.html , (14 Oktober 2012)

Hayati,Rina,2019.Penelitian kepustakaan(Libarary Research),macam dan cara menulisnya.penelitianilmiah.com.https://penelitianilmiah.com/penelitian-kepust aka an/.(24 agustus 2019)

Manis,2019,Pengertian Loyalitas, Karakteristik dan Faktor Penentu Loyalitas Menurut Para Ahli Lengkap.pelajaran.co.id.https://www.pelajaran.co.id/2019/17/pengertianloyalitas-karakteristik-dan-faktor-penentu-loyalitas-menurut-para ahli.html.(17 may2 019)

Rajagukguk,br,Herina,2011.pengertian bisnis menurut para ahli,blogspot.com. http://herina-br.blogspot.com/2011/10/pengertian-bisnis-menurut-paraahli.html.(20 oktober 2011)

Tedja,Zaputra,Hendry.2009.Nilai pelanggan dan loyalitas pelanggan.wordpress.com. https://hendryza.wordpress.com/category/artikel-nilai-pelanggan-dan-loyalitas-pel anggan/.(28 januari 2009)

Ikakartika,2016.jenis jenis pelanggan dan karateristiknya.wordpress.com. https://ikakartika15.wordpress.com/2016/10/11/jenis-jenis-pelanggan-dan-karakte ristik-pelanggan/.(11 okteber 2016)

Aldiunanto,2015.desain dan struktur organisasi ace hardware Indonesia.aldiunanto.com.http://aldiunanto.com/desain-dan-struktur-organisasiace-hardware-indonesia.aldi.(28 may 2015)

Widarti,Peni.2019.Ace Hardware bakal buka gerai tiap tahun.bisnis.com. )https://surabaya.bisnis.com/read/20191030/532/1165086/ace-hardware-bakalbuka-gerai-tiap-tahun.(30 oktober 2019 )

Ace Hardware Indonesia.https://corporate.acehardware.co.id/id/penghargaan?page=1

Modul Hapzi Ali https://elearning .mercubuana.ac.id/plug infile.p hp/33 5409 /mod_resource/content/3/9.\%20Hapzi\%20Ali\%2C\%20Modul\%209\%20HBL\%2C $\%$ 20Perlindungan $\% 20$ Konsumen $\% 20 \% 20$ Tanggungjawab\%20Hk.pdf 